\title{
Retraction
}

\section{Retracted: Intramedullary Chondrosarcoma of Proximal Humerus}

\section{Case Reports in Radiology}

Received 1 March 2016; Accepted 1 March 2016

Copyright (C) 2016 Case Reports in Radiology. This is an open access article distributed under the Creative Commons Attribution License, which permits unrestricted use, distribution, and reproduction in any medium, provided the original work is properly cited.

The article titled "Intramedullary Chondrosarcoma of Proximal Humerus" [1] has been retracted as it was found to contain a substantial amount of material, without referencing, from the following published article: "Review: Imaging of Chondrosarcomas," by L. Ollivier, D. Vanel, and J. Leclère, in Cancer Imaging.

\section{References}

[1] P. Yadav, D. Thakkar, and S. S. Thind, "Intramedullary chondrosarcoma of proximal humerus," Case Reports in Radiology, vol. 2012, Article ID 642062, 7 pages, 2012. 